\title{
Cloning and characterization of the G-box binding factor, an essential component of the developmental switch between early and late development in Dictyostelium
}

\author{
Gavin R. Schnitzler, ${ }^{1}$ Wolfgang H. Fischer, ${ }^{2}$ and Richard A. Firtel ${ }^{1,3}$ \\ ${ }^{1}$ Department of Biology, Center for Molecular Genetics, University of California, San Diego, La Jolla, California \\ 92093-0634 USA; ${ }^{2}$ Clayton Foundation Laboratory for Peptide Biology, The Salk Institute for Biological Sciences, La Jolla, \\ California 92037 USA
}

\begin{abstract}
During Dictyostelium development, the cAMP-regulated induction of cell-type-specific late genes marks a developmental switch from the initial formation of the multicellular organism to the differentiation of the various cell types that mediate morphogenesis and eventually give rise to the mature fruting body. The G-box binding factor (GBF) is a developmentally regulated Dictyostelium transcription factor whose affinity for a DNA sequence correlates with the ability of that sequence to confer inducibility to late gene promoters in response to high, continuous levels of extracellular CAMP. We report the purification of GBF and cloning of the gene that encodes it, as confirmed by in vitro production of GBF activity. The predicted protein is highly basic and contains two putative zinc fingers. Disruption of the GBF gene by homologous recombination results in the loss of all GBF DNA-binding activity, developmental arrest at the loose aggregate stage, and the loss of late gene induction during development or in response to extracellular cAMP. Constitutive expression of GBF complements the null phenotype and allows for the rapid activation of a class of late genes in response to cAMP. Our results indicate that GBF acts as an extracellular cAMP-responsive transcriptional activator regulating late gene expression and is an essential component of a developmental switch between aggregation and cellular morphogenesis.
\end{abstract}

[Key Words: Dictyostelium discoideum; transcription factor; DNA-binding protein; signal transduction]

Received November 11, 1993; revised version accepted December 28, 1993.

An early aggregate of Dictyostelium discoideum cells, formed by the chemotactic aggregation of individual amoebae, must undergo a critical transition whereby it becomes a coherent multicellular organism composed of a number of distinct cell types. High levels of cAMP and other signals in the aggregate mediate this transition by the activation of a variety of genes involved in later development and cellular morphogenesis (for review, see Kimmel and Firtel 1991; Williams 1991). These late genes display a variety of temporal and spatial expression patterns. Some, such as pst-cathepsin/CP2 (hereinafter called $C P 2$ ) and $D d r a s D$ are activated during aggregation and require only high, continuous levels of extracellular cAMP and starvation signals for their expression (Mehdy et al. 1983; Mehdy and Firtel 1985; Reymond et al. 1984). We will refer to these genes as primary late genes. Others, referred to here as secondary late genes, are activated later and require additional signals that may be present only at tight-aggregate or tipped-aggregate stages. For ex-

\footnotetext{
${ }^{3}$ Corresponding author.
}

ample, SP60 and SP70 require as-yet-unspecified cellcell contacts (Mehdy et al. 1983; Mehdy and Firtel 1985; Fosnaugh and Loomis 1991), and $e c m A$ and $e c m B$ require the morphogen DIF (Williams et al. 1987; Berks and Kay 1990). For some, expression is restricted to prestalk and anterior-like cells, such as $e c m A$ and $e c m B$ (Jermyn and Williams 1991), or is prestalk enriched, such as $C P 2$ (Pears et al. 1985; Gomer et al. 1986a) and DdrasD (Reymond et al. 1984; Jermyn et al. 1987; Esch and Firtel 1991). Others, such as SP60 (Haberstroh and Firtel 1990), PspB (Powell-Coffman and Firtel 1994), and SP70 (Fosnaugh and Loomis 1993), are expressed only in prespore cells. What unites these diverse genes is their late activation (after the onset of aggregation) and their induction by, or requirement for, continuous micromolar levels of cAMP (Mehdy et al. 1983, Mehdy and Firtel 1985; Haribabu and Dottin 1986; Berks and Kay 1990; Fosnaugh and Loomis 1991).

The promoters of many late genes contain CA/GTrich sequences that have been shown to be essential for their activation during development or in response to cAMP [Haberstroh and Firtel 1990; Haberstroh et al. 
1991 (SP60); Fosnaugh and Loomis 1993 (SP70); PowellCoffman and Firtel $1994(P s p B)$; Ceccarelli et al. 1991, $1992(\mathrm{ecmB})$; Early et al. 1993 (ecmA); Datta and Firtel 1987, 1988; Pears and Williams 1987 (pst-cathepsin/ CP2); Pavlovic et al. 1989 (UDPGP); Esch et al. 1992 $(D$ dras $D)$. The G-box binding factor, or GBF, is a developmentally regulated activity that binds specifically to a number of CA/GT-rich late gene regulatory elements [Hjorth et al. 1989 (CP2 and DdrasD); Hjorth et al. 1990 (UDPGP); Ceccarelli et al. $1992(\mathrm{ecmB})$; J. Powell-Coffman, G. Schnitzler, and R.A. Firtel, in prep. (SP60); Powell-Coffman and Firtel $1994(P s p B)]$, as well as similar sequences from late gene promoters yet to be analyzed for cis elements [Hjorth et al. 1990 (CP1 and DG17)]. Each of these GBF-binding sequences contains two halfsites of the rough consensus $(T / G) G(G / T) G(T / G) G(T /$ $\mathrm{G})$, and the spacing and orientation between these sites is flexible (Hjorth et al. 1990; G. Schnitzler and R. Firtel, unpubl.). Where it has been tested, GBF's affinity for a binding site in vitro correlates with the ability of that sequence to restore CAMP inducibility to a mutated late gene promoter, $C P 2 \Delta 30$, in vivo (Pears and Williams 1988; Hjorth et al. 1989, 1990; C. Gaskins, G. Schnitzler and R. Firtel, unpubl.). In addition, mutant sequences that act as poor GBF binding sites in vitro function poorly in facilitating the developmental expression of the SP60 promoter (Haberstroh et al. 1991; J. PowellCoffman, G.R. Schnitzler, and R.A. Firtel, in prep.). Taken together, these data indicate that GBF may be a transcriptional activator of a wide variety of late genes in response to cAMP.

To examine further the role of this factor in the regulation of late genes, we have purified GBF and cloned the gene that encodes it. This is the first DNA binding protein to be cloned by virtue of its function in Dictyostelium. Analysis of $g b f^{-}$null cells demonstrates that GBF is required for post-aggregative development and late gene expression in response to extracellular cAMP. Constitutive expression of GBF allows cells to rapidly activate the primary late gene $C P 2$ in response to cAMP. Our results indicate that GBF functions as a transcription factor that is part of a developmental switch between the initial formation of the multicellular organism and cellular morphogenesis.

\section{Results}

\section{Purification and apparent molecular weight of $G B F$}

Earlier examination of GBF DNA-binding activity used nuclear extracts because of difficulties in observing specific complexes in cytosolic extract preparations /Hjorth et al. 1989). Optimization of the mobility-shift assay (see Materials and methods) has made it possible to observe a specific GBF complex (as determined by Rf comparison and competition with wild-type and mutant GBF-binding sites) in cytosolic extracts. GBF activity is $\sim 22$-fold enriched in the cytosol (Fig. 1A), and present as $\sim 5000$ molecules per 17-hr developed cell.

GBF was purified $\sim 3000$-fold from 17-hr cytoplasmic
A

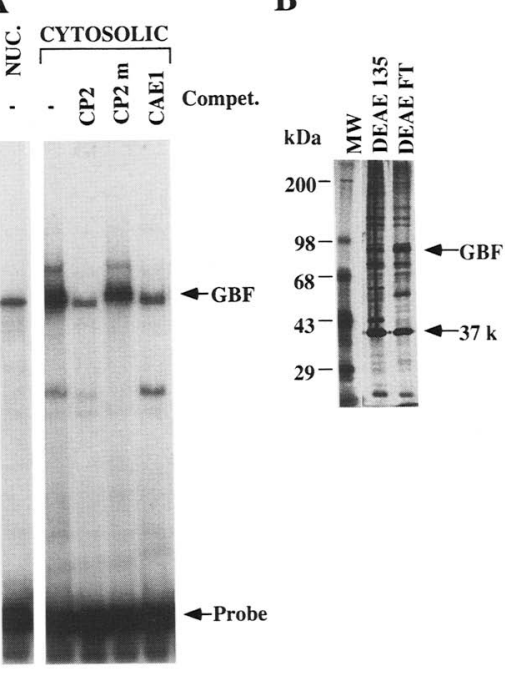

C

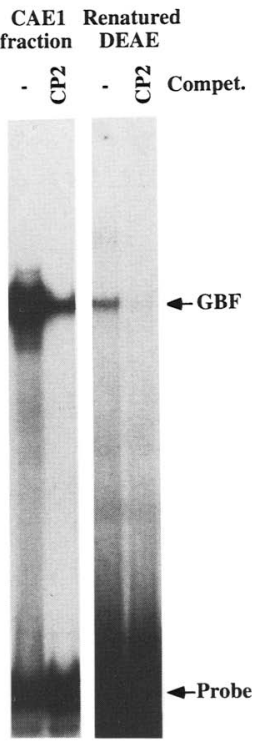

Figure 1. GBF purification and apparent molecular mass. $|A|$ Cytosolic and nuclear extracts were prepared from 17-hr developed cells and tested in an electrophoretic mobility shift assay (EMSA), as described in Materials and methods, with $800 \mathrm{ng}$ of poly $[\mathrm{d}(\mathrm{I}-\mathrm{C})]$ as a nonspecific competitor. Specific competitors are $\mathrm{CP} 2$, mutant $\mathrm{CP} 2(\mathrm{CP} 2 \mathrm{~m})$, and CAE 1 as indicated. $(B)$ DEAE fractions were precipitated with TCA and subjected to SDSPAGE on a $7.5 \%$ acrylamide gel. Molecular weight markers are from Bio-Rad, and the gel was stained with silver nitrate. $(C)$ The 92-kD GBF band in the DEAE flowthrough fraction was excised from a Coomassie blue stained 7.5\% SDS-PAGE gel, and proteins were eluted, renatured, and tested by EMSA using only $200 \mathrm{ng}$ poly[d $\mathrm{d}(\mathrm{I}-\mathrm{C})]$. CP2 competitor is present in the indicated lanes. A CAEl affinity column control fraction is also shown exposed for $\sim 10$-fold less time.

extracts, with a $40 \%$ recovery of binding activity, by use of sequential chromatography on DNA cellulose, SP60 CAE-1 affinity resin and DEAE Sepharose (Table 1). To use SDS-PAGE as a final stage in the purification process, it was necessary to determine the apparent molecular mass of all protein species that constitute GBF activity. To accomplish this, various fractions from the

Table 1. Purification of GBF activity

\begin{tabular}{lccc}
\hline Fraction & mg & Units GBF & $\begin{array}{l}\text { Fold } \\
\text { purification }\end{array}$ \\
\hline 17-hr cytosolic extract & 751 & 285,500 & - \\
DNA-cellulose & 12 & 174,000 & 38 \\
CAEl affinity & $\sim 1.8$ & 146,000 & $\sim 215$ \\
DEAE FT & $\sim 0.1$ & 115,100 & $\sim 3000$ \\
\hline
\end{tabular}

Results of the purification of cytosolic extracts from $1 \times 10^{11}$ 17-hr developed cells are shown. Protein levels were determined by Bio-Rad protein reagent for extracts and DNA-cellulose fractions, and estimated by examination of stained SDS-PAGE gels for later fractions. Units of GBF activity were calculated as described in Materials and methods. 
purification were size-separated by SDS-PAGE, lanes were cut into sections, and proteins eluted, renatured, and assayed (see Materials and methods). By use of crude extracts, specific GBF activity was demonstrated to run between 68 and $95 \mathrm{kD}$, and renatured proteins from other size ranges could not increase or modify this binding activity (data not shown). In fractions from the DEAE chromatography, a single band at $\sim 92 \mathrm{kD}$ /comprising $\sim 30 \%$ of total protein; see Fig. 1B) was isolated and renatured to give specific GBF activity (Fig. 1C). The amount of this band correlated with level of GBF activity throughout the purification (data not shown). From these results, we concluded that GBF activity can be accounted for by a single $92-\mathrm{kD}$ protein species (or multiple species of the same size).

\section{Isolation of tryptic fragments and cloning of the gene encoding $G B F$}

DEAE fractions containing GBF activity were precipitated, run on SDS-PAGE, blotted onto PVDF membrane, and stained (see Materials and methods). The isolated $92-\mathrm{kD}$ band was subjected to digestion with trypsin, and peptides released were isolated by HPLC. Four HPLC peaks were sequenced yielding the following partial peptide sequences: $1033, \quad(\mathrm{~S}) \mathrm{NI}(\mathrm{T}) \mathrm{PI}(\mathrm{T}) \mathrm{D}(\mathrm{S})(\mathrm{L} / \mathrm{S})(\mathrm{T})(\mathrm{S})(\mathrm{D})$; 1035, (L/K)PFTP(W/V)G AG(L/K)SP(S); 1037, AFTPGITK, 1042; DS(S/C)GQTIPK. Letters in parentheses indicate indefinite assignments, with letters preceding a slash indicating the most likely amino acid.

Six degenerate oligonucleotides were designed from three of the peptide sequences (1035, 1037, and 1042), as sense and antisense pairs, and used in pairwise combinations to amplify Dictyostelium genomic DNA by PCR. One combination (1037-sense and 1035-antisense) gave a product of $\sim 480 \mathrm{bp}$, which was cloned and used to isolate multiple, overlapping, partial cDNAs from a 12- to 16-hr developmental cDNA library (Fig. 2). A Southern blot using the PCR product as probe indicated that the GBF gene is present in a single copy (data not shown). A genomic map of the region surrounding GBF is presented in Figure 2. The PCR product was used to screen a Dictyostelium YAC library (Kuspa et al. 1992), and it hybridized to a single YAC, which has not yet been incorporated into a linkage group (A. Kuspa and W.F. Loomis, pers. comm.).

\section{GBF protein contains two putative zinc fingers}

The overlapping cDNAs contain one long open reading frame (starting at position 215 and ending at position 2340 from the $5^{\prime}$ end of the cDNAs). This encodes a 708-amino-acid protein (predicted molecular mass of $79.3 \mathrm{kD}$ ), in which all four of the sequenced peptides could be found (underlined sequences, Fig. 3A), confirming that the gene cloned encodes the protein that was purified. The protein contains very few acidic residues and has a predicted $\mathrm{pI}$ of 9.76 . The $\sim 13-\mathrm{kD}$ difference between observed and predicted molecular mass might result in part from the basic nature of the protein, as highly basic proteins, such as histone $\mathrm{Hl}$, often run on SDS-PAGE with an apparent molecular mass larger than their actual mass (Lennox and Cohen 1989), or may indicate that GBF is post-translationally modified in vivo. GBF is predicted to be highly hydrophilic (Kyte and Doolittle 1982) and to contain a preponderance of turns, occasional short stretches of $\beta$-sheet and very little $\alpha$-helix (Chou and Fasman 1978, Garnier et al. 1978; data not shown).

GBF has no extensive homology to any known protein (BLAST search of nr library at NCBI; Altschul et al. 1990|, except over the long Gln- and Asn-rich stretches of GBF. One such region of GBF $163 \%$ Gln and $19 \%$ His over 150 amino acids) contains four near-perfect direct

Figure 2. GBF genomic organization and constructs. The genomic organization of GBF was determined by restriction endonuclease digestion and Southern blotting with the subcloned PCR product and GBF cDNAs as probes. The GBF cDNA, as well as transformation and expression constructs, are shown aligned with the genomic DNA (see Materials and methods for details). White and black boxes indicate coding and noncoding GBF sequences, respectively. Dark grey boxes within the GBF coding region show the positions of the two $\mathrm{Cys}_{4}$ repeats. Comparison of endonuclease digestions of the cDNA and genomic DNA suggests the absence of long introns within

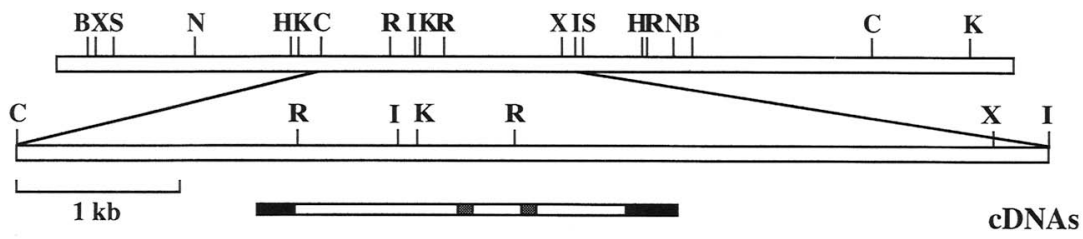
the region encompassed by the cDNA. In the constructs, black lines indicate vector sequences, and labeled, shaded boxes are non-GBF Dictyostelium and/or bacterial sequences. Arrows indicate the direction and position of promoters used in the expression constructs. Thyl represents the Thy1 gene used for auxotrophic selection in JH10 cells for the gene disruption (see Materials and methods). Restriction enzyme sites shown are BgIII (B), XbaI $(\mathrm{X}), \operatorname{SpeI}(\mathrm{S}), N d e \mathrm{I}(\mathrm{N}), H i n d I I I$ $(\mathrm{H}), \operatorname{KpnI}(\mathrm{K}), \operatorname{ClaI}(\mathrm{C}), \operatorname{EcoRI}(\mathrm{R}), \operatorname{HincII}(\mathrm{I}), \operatorname{ApaI}(\mathrm{A})$, and SacI (Sa). 
MLSTHHHQGNSSSSSSSSSPSQTIGGSDLSNISALPLPLPSIFTTAQNQM 50 NPPILFPPTSSLLGGSSNTPSFLLPPSSIMSSNVFPSHDGQYPDMPNMVD 100 QYQIHPNQNPHYNYQYQLMFMQQQAQQNQPPQQNQQQQHHQQQQQQPQHH 150 QQMQQQQHHQQMQQQQQHHQQMQQQQHHQQMQHHQLQQHQHOHQQQQQQQ 200 QHQQQHHQQQQQQQQQHHQQQQHHQHSQPQQQHQHNQQQQHQHNQQQHQQ 250 QQNQIQMVPQQPQSLSNSGNNNNNNNNNNNNSNNNNNNNNNNNNSHQLNNITT 300 LSQNNTSGSNTPSPSTKGKRKHHETSNSEKKDSSGQTIPKCTRCNEAASW 350 KHDKRRWWCKECKKAFTPCITKMQQVPQQAQLQPLQNHNQIIPQLWDSQQ 400 NNSSQNTPPTQPQNNMNQINHQLLQQQHQQAQLQAHLNLTASNQQVPPQL 450 QQQINGGLPNNNNSLITQNTLNSLSTSVSCPPCPLCRGISSWKHDKKRYF 500 CKECKKPFTPVGAGLSPSSSPSSPKKKSNITPITTSSTSSSSSTPSIINN 550 NNNNNNANSSKNNTPKKQLSPPPSVLQSPSSSSISQSPLQLNYQTPTCSPN 600 PSLPSIGGNLNSQANSIKPDGGILISGLSPPKSSSSLNNLNSFSNTGALL 650 SSNGINLANLGNPLSQLNKKQKKRSDKDINDGGVQVLVSCVDTNVNNNCSS 700 IIPDGDSW
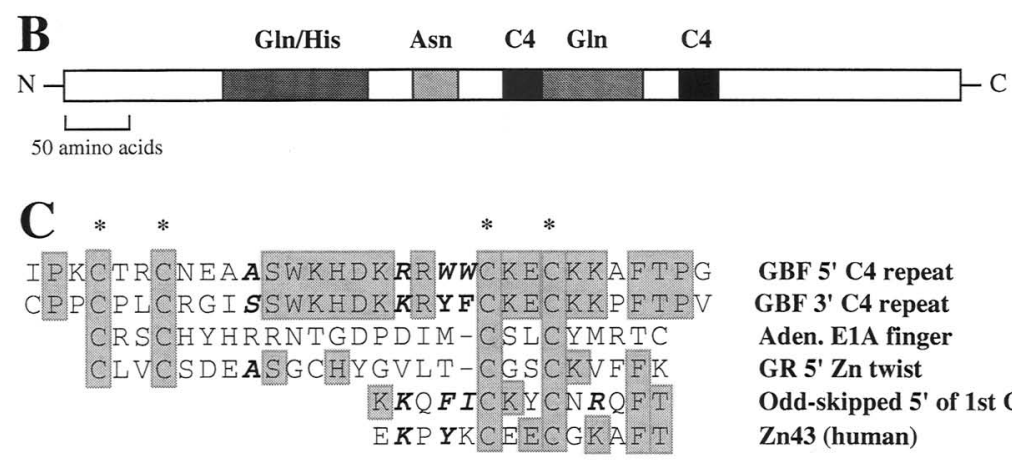

GBF 5' C4 repeat GBF 3' C4 repeat Aden. E1A finger GR 5' Zn twist Odd-skipped 5 ' of 1 st $\mathrm{C}_{2} \mathrm{H}_{2}$ Zn43 (human)
Figure 3. Derived amino acid sequence of GBF. (A) The positions of the four sequenced peptides are indicated by underlining. The two $\mathrm{C}_{4}$ repeats are indicated by shaded boxes. Bold italics indicate the QQQQHHQQM repeats. $(B)$ Schematic of GBF protein structure. Histidine/ glutamine-, glutamine- and asparagine-rich regions are labeled and shaded in progressively lighter shades of gray. The two $\mathrm{C}_{4}$ repeats are shown as black boxes. $(C)$ Alignment of the $\mathrm{GBF} \mathrm{C}_{4}$ repeat regions to each other and to a number of putative zinc finger sequences. Boxes indicate regions absolutely conserved. Bold italics indicate conservative changes. Sequences for other proteins were obtained from glucocorticoid receptor (GR) (Pabo and Sauer 1992); adenovirus E1A (Bruder et al. 1992); Drosophila melanogaster odd-skipped and human $\mathrm{Zn43}$ (the Swiss Protein data base at NCBI). repeats of the sequence QQQQHHQQM (italics in Fig. 3A). The Gln-rich regions of the Oct-1, Oct-2, and Sp1 transcription factors have been shown to function as trans-activation domains (Muller-Immergluck et al. 1990; Seipel et al. 1992; Courey and Tjian 1988), and regions high in glutamine exist in many Drosophila developmental regulatory proteins (Wharton et al. 1985). However, Gln and Asn runs of unknown function have also been found in many Dictyostelium proteins, including some proteins whose homologs in other systems lack such repeats (Shaw et al. 1989; Burki et al. 1991; Mann and Firtel 1991; Pitt et al. 1992; Rutherford et al. 1992).

GBF contains two 30 amino-acid regions that share $63 \%$ identity. Each contains four cysteines and bears reasonable homology to known zinc fingers. Oddly, the highest homology is found between the carboxy-terminal half of the GBF sequences and the amino-terminal (cys2) half of many $\mathrm{C}_{2}-\mathrm{H}_{2}$ zinc fingers (Fig. 3C). These repeats also share 9 of 21 of the most highly conserved residues of the carboxy-most $\mathrm{C}_{4}$ zinc twist region of ste$\mathrm{roid} /$ thyroid receptor proteins (Pabo and Sauer 1992). In addition the $\mathrm{C}-X_{2}-\mathrm{C}-X_{14}-\mathrm{C}-X_{2}-\mathrm{C}$ arrangement of cysteine residues is similar to the $\mathrm{C}-X_{2}-\mathrm{C}-X_{13}-\mathrm{C}-X_{2}-\mathrm{C}$ arrangement found in a number of other putative zinc finger structures (Bruder et al. 1992).

\section{In vitro expresssion of $G B F$ protein}

To confirm that the cloned gene encodes the specific GBF-binding activity, we expressed GBF in an in vitro transcription/translation system (see Materials and methods). To facilitate its expression, we changed the sequence around the initiation codon to include a nearconsensus mammalian start site (Kozak 1983) and made the second codon compatible with mammalian codon usage (Grantham et al. 1981). A DNA-binding activity with the same Rf and binding specificity as GBF was present in GBF-programmed lysates, but not in control lysates (Fig. 4A), confirming that the gene cloned encodes GBF-binding activity. An $\sim 88 \mathrm{kD}$ protein was specifically labeled in GBF-programmed lysates (data not shown).

GBF is developmentally regulated and induced by extracellular cAMP

Northern blot analysis of RNAs isolated from cells at various times during development indicates that the $G B F$ gene encodes a single transcript of $\sim 3.8 \mathrm{~kb}$ that is very weakly expressed in vegetative cells, is induced at $\sim 4 \mathrm{hr}$ of development, and is expressed at similar levels 
A

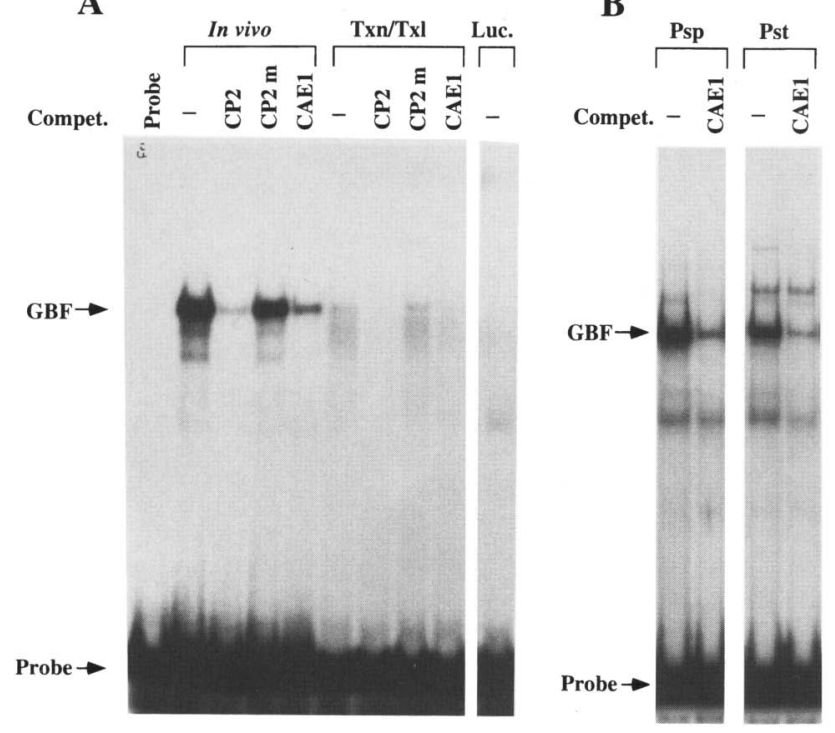

Figure 4. Electrophoretic mobility shifts of in vitro-translated GBF and separated cell extracts. $(A)$ One microliter of DNAcellulose-purified GBF is compared with $1 \mu$ l of TnT rabbit reticulocyte lysates programmed with the GBF expression construct R20 (Txn/Txl) or a control construct expressing luciferase (Luc.) by EMSA. The dried gel was exposed to X-ray film with an intervening film to screen out ${ }^{35} \mathrm{~S}$ radiation from labeled proteins. $(B) \mathrm{KAx}-3$ cells were developed for $16 \mathrm{hr}$ at a density of $5 \times 10^{6}$ cells $/ \mathrm{cm}^{2}$ on buffered agar and separated into prestalk and prespore populations by Percoll gradient centrifugation (see Materials and methods|. Cytoplasmic extract of separated cells $(1.2 \mu \mathrm{g})$ was examined by EMSA. CAEl competitor is present in the indicated lanes. Fold enrichment was determined by use of ecmA (prestalk-specific) and $P s p B$ (prespore-specific) RNAs as markers to measure cross-contamination of the separated cell types.

throughout the remainder of development (see Fig. 7, below). The transcript is $1.2 \mathrm{~kb}$ larger than the contiguous cDNAs isolated so far, which is presumably due to additional 5 '- and/or 3 '-untranslated sequence. Other RNA time courses show a low level of GBF transcripts at 3 and $4 \mathrm{hr}$ (data not shown). The variability at the $4-\mathrm{hr}$ time point may indicate that GBF expression is first induced at this time, making it sensitive to slight differences in developmental conditions. The RNA time course correlates with the developmental induction of GBF-binding activity in extracts, which is low in vegetative cells and at $5 \mathrm{hr}$ but increases to a steady-state level at $10 \mathrm{hr}$ (Hjorth et al. 1989; see Discussion).

All late genes tested can be induced in shaking culture with the addition of micromolar levels of extracellular cAMP after a period of starvation. The primary late genes (such as $C P 2$ and DdrasD, see introductory section) can be activated under fast-shake conditions, in which high rotational speed and EDTA keep cells from clumping (Mehdy et al. 1983; Mehdy and Firtel 1985; Reymond et al. 1984). Others, such as SP60 (Mehdy et al. 1983; Mehdy and Firtel 1985; Fosnaugh and Loomis 1991) and $e c m A$ (see Fig. 8, below; Berks and Kay 1990), require the clustering of cells allowed in slow-shake cultures. GBF activity has been shown to be induced by starvation followed by cAMP in slow-shake culture (Hjorth et al. 1989). Figure 8 (below) shows that the GBF transcript can be activated fivefold by starvation for $6 \mathrm{hr}$. This expression level is the same at 3 and $9 \mathrm{hr}$ of starvation (data not shown), and a similar increase in GBF-binding activity is observed in extracts from 4-hr starved cells (see Fig. 6A, below|. Unlike early aggregation-stage genes, $G B F$ expression is largely uneffected by $30 \mathrm{nM}$ pulses of cAMP given every $6 \mathrm{~min}$ for either 3 or $6 \mathrm{hr}$ (data not shown). $G B F$ expression is, however, rapidly activated by $300 \mu \mathrm{M}$ cAMP under both fast- and slow-shake conditions (threeto fourfold in $1 \mathrm{hr}$ ). GBF transcription is activated in slow shake without cAMP, an effect also observed for other primary late genes [Mehdy et al. 1983 (CP2); Reymond et al. 1984 (Ddras $D$ ); see below], which may result from a buildup of cAMP, or other potential activating signals, in clumps of cells.

To examine the cell-type distribution of GBF, RNAs from 16-hr developed cells were separated by Percoll gradient centrifugation into prespore and prestalk populations (see Materials and methods). GBF was present in cytoplasmic extracts made from both prestalk and prespore cells, although it was 2.8 -fold enriched in prespore cells (Fig. 4B). GBF transcripts showed a similar (2.5-fold) enrichment in prespore cells (data not shown).

\section{GBF gene disruptants are arrested at the loose mound stage}

A GBF gene disruption was made by use of the Thy1 selectable marker transformed into JH10 cells (Fig. 2). Whereas all nondisrupted clones displayed wild-type development, all disrupted clones $\left(g b f^{-}\right)$were delayed in aggregation by $\sim 2 \mathrm{hr}$ and arrested at the loose aggregate stage (Fig. 5A), forming high mounds after $\sim 12 \mathrm{hr}$, but never producing a tip or sheath. At $\sim 20 \mathrm{hr}$, the high mounds partially disperse, only to reform $\sim 4-6 \mathrm{hr}$ later (cf. $g b f^{-}$null cells at 12, 20, and $24 \mathrm{hr}$; Fig. 5A).

To address whether $g b f^{-}$null cells could participate in development along with wild-type cells, $g b f^{-}$cells were transformed with a construct containing the $\beta$-galactosidase gene driven by the Actin15 (Act15) promoter. This promoter is expressed most strongly in early development yet continues to be expressed at reasonable levels throughout development (Knecht et al. 1986) and roughly equally in all cell types (Mann and Firtel 1993). These cells were then mixed with wild-type cells, allowed to develop for various times, fixed, and stained for $\beta$-galactosidase (see Materials and methods). Figure 5B shows that $g b f^{-}$cells can move to the same aggregation centers as wild-type cells, although perhaps more slowly, but are then left behind when the wild-type cells form later developmental structures, demonstrating the cell autonomous nature of GBF function.

Cytoplasmic extracts of vegetatively grown $g b f^{-}$null cells and extracts of $g b f^{-}$cells after $4 \mathrm{hr}$ of starvation in shaking culture or $16 \mathrm{hr}$ of development showed no detectable GBF-binding activity (Fig. 6A; data not shown). 
A

Wild-Type $6 \mathrm{hr}$

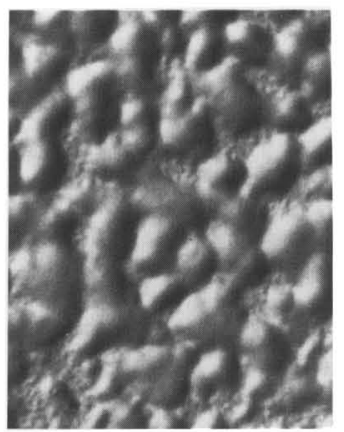

Wild-Type $13 \mathrm{hr}$

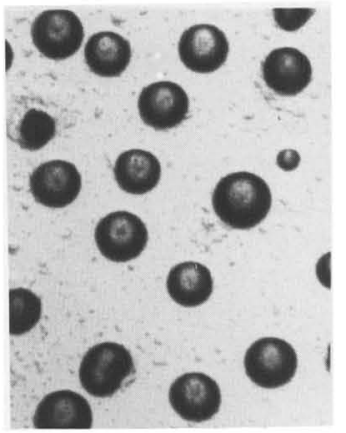

$g b f-12 \mathrm{hr}$

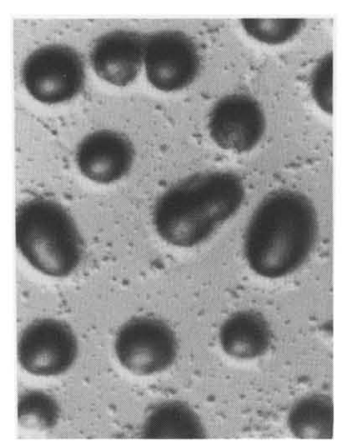

A 15-GBF $6 \mathrm{hr}$

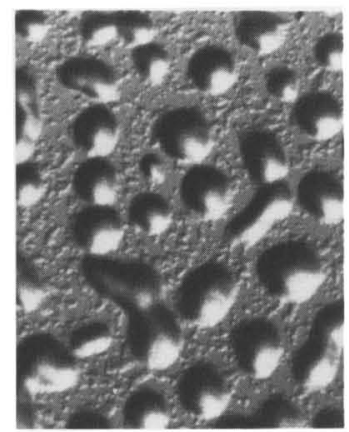

A15-GBF $13 \mathrm{hr}$

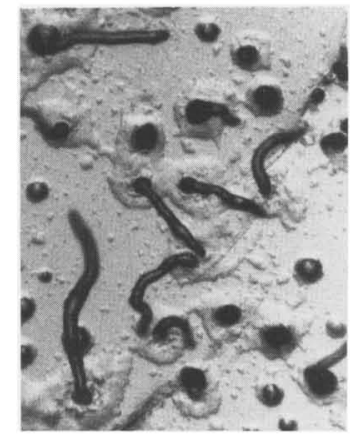

$g b f-20 \mathrm{hr}$

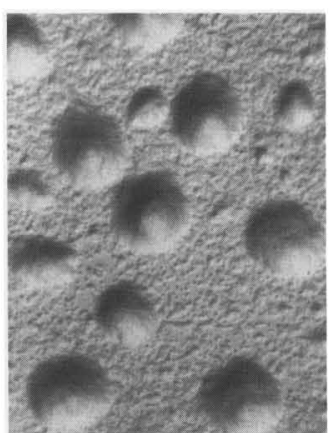

Wild-Type $24 \mathrm{hr}$

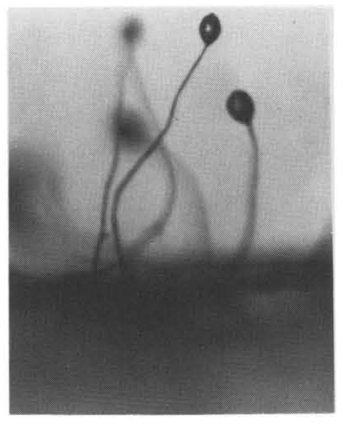

A 15-GBF/gbf- $24 \mathrm{hr}$

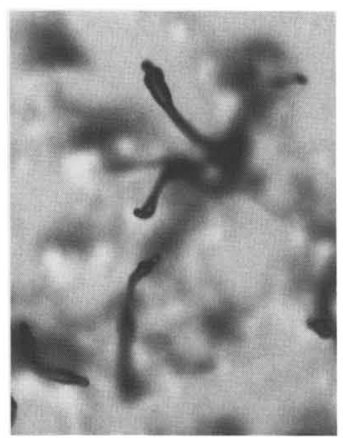

$g b f-24 \mathrm{hr}$

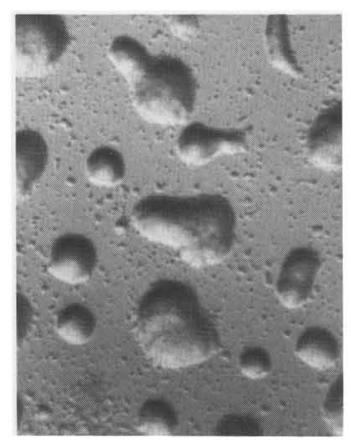

B
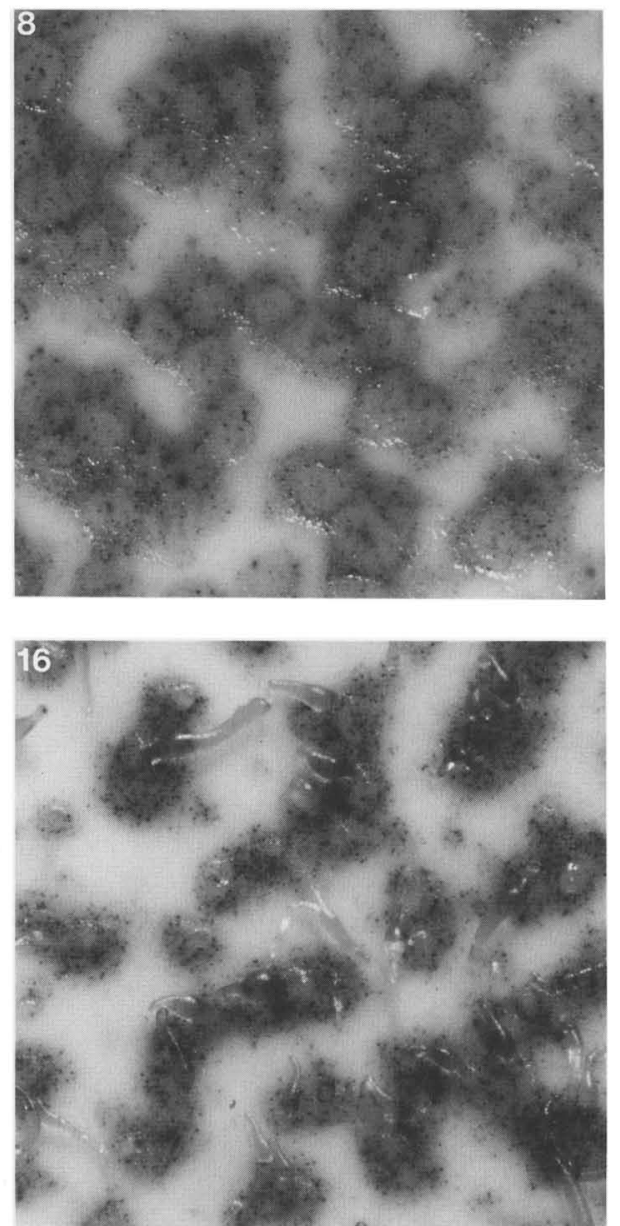

Figure 5. Morphological phenotypes of $G B F$ disruptants and overexpressors. (A) Cells were grown axenically, washed, and plated at between $\sim 7.5 \times 10^{5}$ and $\sim 1.5 \times 10^{6}$ cells $/ \mathrm{ml}$ on sodium phosphate-buffered agar. Cell line and time of development are indicated. $(B)$ Wild-type KAx-3 and a clonal population of $g b f^{-}$cells transformed with the Act15-lacZ construct were grown axenically, washed, mixed in a 1:1 ratio, and plated at $\sim 1 \times 10^{6}$ cells $/ \mathrm{ml}$ on Millipore filters over buffer. At the indicated times in development 18 or 16 $\mathrm{hr}$ ) the cells were fixed and stained with X-gal as described in Materials and methods.

This result confirms that the cloned GBF gene is responsible for all of the detectable GBF-binding activity in extracts. In addition, $g b f^{-}$cells produced no GBF transcript under either shaking culture or plated development conditions (Figs. 8 and 7, respectively).

\section{Constitutive GBF expression complements $\mathrm{gbf}^{-}$cells and accelerates development}

To prove that the disruption phenotype is not due to a secondary mutation, the complete GBF cDNA was in- troduced into $\mathrm{gbf}^{-}$null cells under control of the Act15 promoter (construct A15-GBF). All A15-GBF/gbfclones contained multiple tandem copies of the introduced DNA and expressed high levels of a $3.6-\mathrm{kb}$ A15GBF transcript (data not shown). Each transformant displayed at least a partial rescue of the $g b f^{-}$phenotype (Fig. 5A). The somewhat abnormal morphology of postaggregative structures is probably due to differences in the expression pattern of the Act 15 and GBF promoters. In cytoplasmic extracts from 4-hr starved A15-GBF/ $g b f^{-}$cells, a specific mobility-shift band at the same Rf 
A

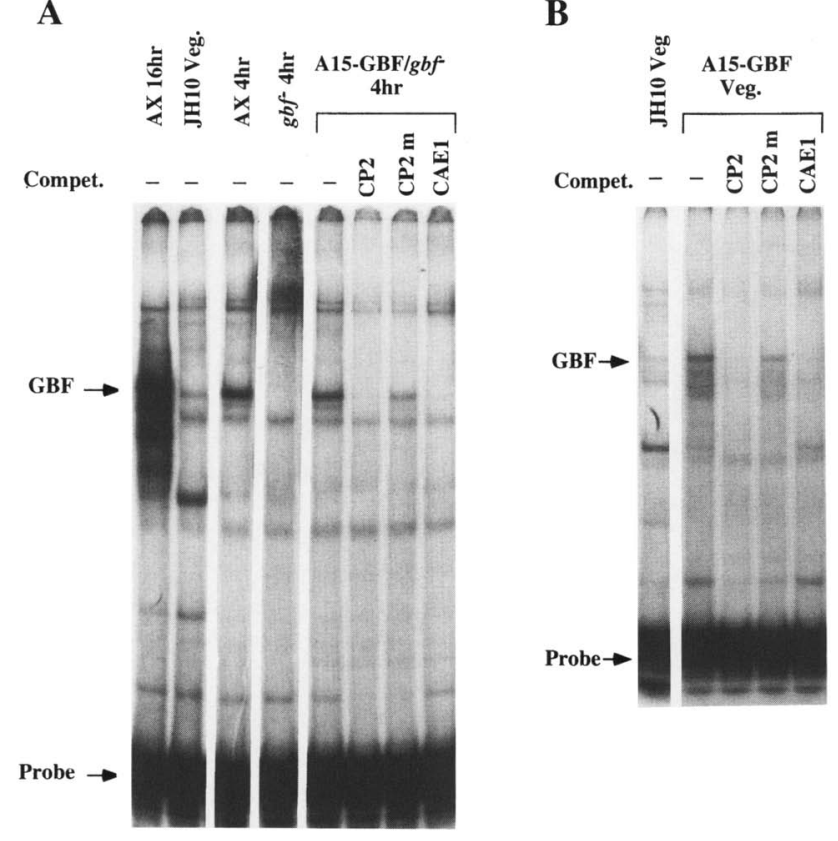

Figure 6. GBF activity in extracts of $g b f^{-}, \mathrm{Al}, \mathrm{GBF} / g b f^{-}-$ and A15-GBF cells. (A) Cytoplasmic extracts were prepared from $16-\mathrm{hr}$ developed $\mathrm{KAx}-3$, vegetative $\mathrm{JH} 10$ cells, and AX3, $g b f^{-}$, and A15-GBF/gbf- cells starved for $4 \mathrm{hr}$ in shaking culture. Each extract $(1.8 \mu \mathrm{g})$ was tested by EMSA. (B) A cytoplasmic extract of vegetative $\mathrm{JH} 10$ and $\mathrm{A} 15-\mathrm{GBF}$ cells $(1.8 \mu \mathrm{g})$ was tested by EMSA.

of wild-type GBF was seen (Fig. 6A), further confirming that the cloned sequences encode the complete GBF protein.

The A15-GBF construct was transformed into wildtype KAx-3 cells to generate the A15-GBF cell line. These cells express both the 3.8 -kb endogenous GBF and 3.6-kb A15-GBF transcripts (Fig. 7). These overexpressing cells are consistently smaller than wild-type cells when grown in monolayer or shaking culture (data not shown). When plated for development, these cells formed tight aggregates and slugs 1-2 hr ahead of wildtype cells. The morphology of developmental structures is nearly wild type, although slugs are more elongated, and a larger proportion of cells failed to enter aggregates (cf. wild-type cells at 6 and $13 \mathrm{hr}$ to A15-GBF cells at 6 and $13 \mathrm{hr}$, Fig. 5A). Vegetative cytoplasmic extracts from this strain contain at least eightfold more GBF activity than extracts from wild-type cells (Fig. 6B).

\section{$G B F$ is required for late gene activation by cAMP}

We examined the expression of a number of developmental marker gene mRNAs in wild-type, $g b f^{-}$and A15GBF cells. Most of these genes are late genes that contain important CA/GT rich elements to which GBF has been shown or might be expected to bind $(S P 60, e \mathrm{~cm} A, C P 2$, and DdrasD; see introductory section). Two others are early, aggregation-stage genes that are activated by nanomolar pulses of cAMP and repressed by the continuous micromolar concentrations that activate late genes [Mann and Firtel 1987 (D2); Gerisch et al. 1975; Ma and Siu 1990 (csA)l, and should not require GBF for their expression. CP2 (Fig. 7) is one of the first late genes to be expressed, beginning at the initial stages of mound formation $(\sim 6 \mathrm{hr})$. In $g b f^{-}$cells the CP2 transcript is only very weakly expressed at 8 and $20 \mathrm{hr}$ (partially dispersed aggregates| but not at times when high mounds are present. The reinduction at $20 \mathrm{hr}$ is also seen for the early, aggregation-stage genes $D 2$ and $\operatorname{cs} A$ (see below) and indicates that this residual $C P 2$ expression is responding to signals that activate these genes. Accordingly, we have found that $C P 2$ can be activated to a similar, low level by $30 \mathrm{nM}$ pulses of cAMP (A. Clark, G.R. Schnitzler and R.A. Firtel, unpub.), which induce the aggregation-stage genes. Characteristic of primary late genes, CP2 expression can be highly activated, after a period of starvation, by the addition of continuous micromolar levels of cAMP to fast-shaking culture. This response is abolished in $g b f^{-}$null cells (Fig. 8). Similar

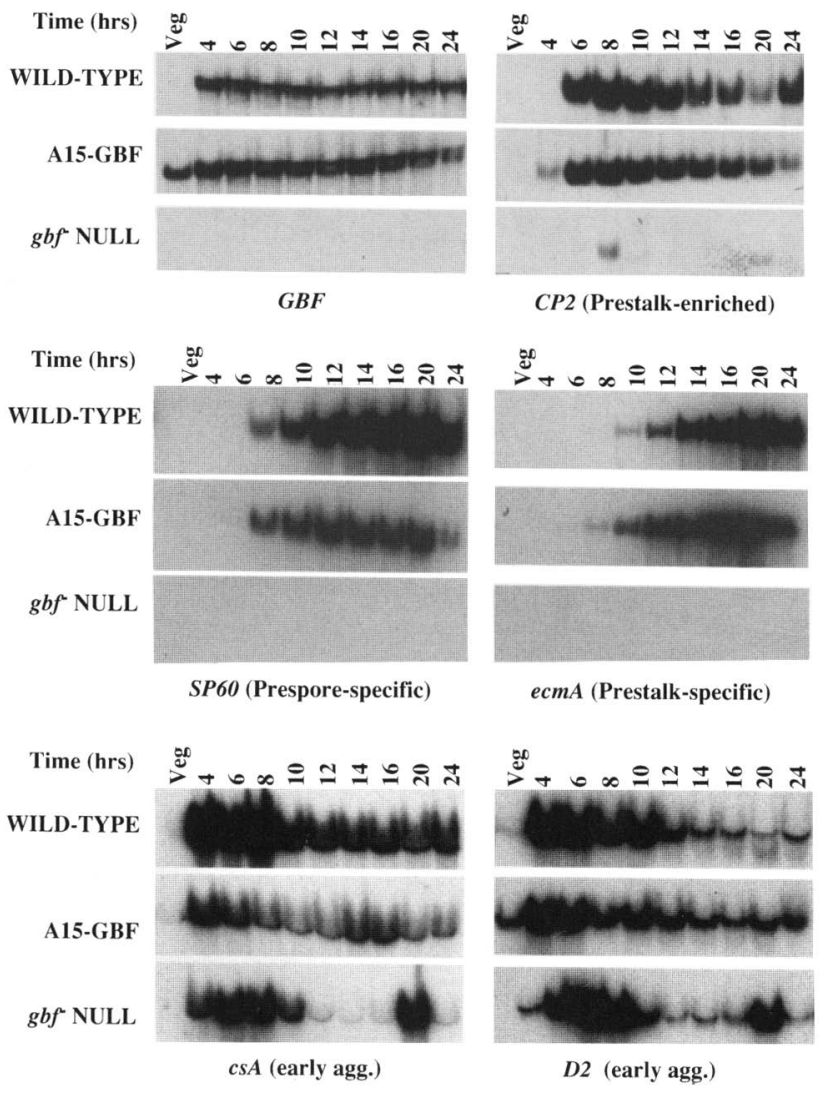

Figure 7. Developmental regulation of GBF and marker genes in wild-type, $g b f^{-}$, and A15-GBF cells. RNA was collected from KAx-3 (WILD-TYPE), A15-GBF, and $g b f^{-}$null cells developed at a density of $\sim 6 \times 10^{6} \mathrm{cells} / \mathrm{cm}^{2}$ on filters for the indicated times. These RNAs $(6 \mu \mathrm{g})$ were size separated, blotted, and probed. Probes are GBF, CP2, SP60, ecm A, csA, and D2 as indicated. 


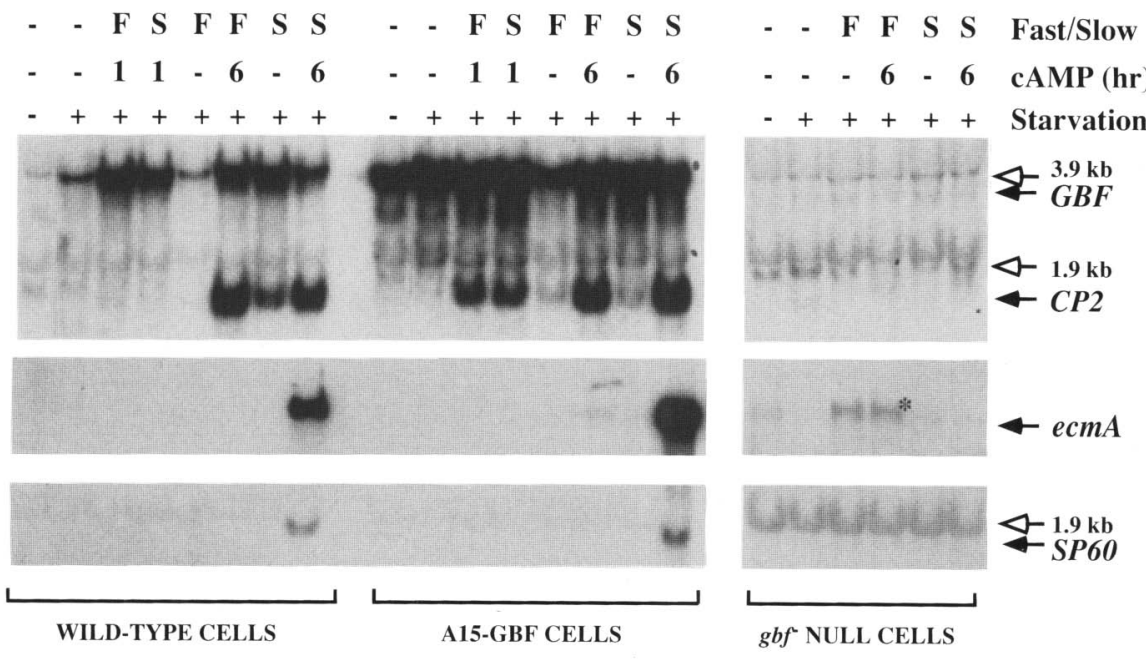
incubation after $6 \mathrm{hr}$ was at $130 \mathrm{rpm}$. Size-separated RNAs $(7 \mu \mathrm{g})$ were blotted and probed with $G B F, C P 2, e \mathrm{~cm} A$, and $S P 60 \mathrm{DNAs}$ Solid arrows indicate the positions of these transcripts: open arrows indicate weak hybridization to the 3.9- and 1.9-kb ribosomal transcripts. An asterisk in the $g b f^{-}$panel probed with ecmA marks the position of a spurious band that runs slightly larger than the major $e m A$ transcript.

results were observed for another primary late gene Ddras $D$ whose transcripts never accumulate above the low levels present at $4 \mathrm{hr}$ of development or after $6 \mathrm{hr}$ of starvation in $g b f^{-}$cells (data not shown). Thus, although primary late genes can respond weakly to early developmental signals in the absence of GBF, their response to continuous micromolar cAMP is completely dependent on GBF.

In A15-GBF cells, the developmental expression of $C P 2$ is accelerated, first appearing very weakly in vegetative cells, and accumulating to easily detectable levels at $4 \mathrm{hr}$ (Fig. 7). This result implies that constitutively expressed GBF can trans-activate $C P 2$, although additional developmental signals are required for maximal expression. To address the nature of this requirement, we tested the cAMP-inducibility of CP2 in A15-GBF cells in shaking culture. After $6 \mathrm{hr}$ of starvation, wildtype cells respond to micromolar cAMP with a slow rise in CP2 mRNA levels, from $<2 \%$ after $1 \mathrm{hr}$ to $100 \%$ after $6 \mathrm{hr}$. By contrast, treatment of $6 \mathrm{hr}$-starved A15-GBF cells with cAMP for $1 \mathrm{hr}$ activates CP2 to $\sim 35 \%$ of the starved + $6 \mathrm{hr}$ cAMP levels for either wild-type of A15GBF cells. This rapid activation is consistent with the hypothesis that GBF is a limiting component of the signaling system that activates CP2 in response to high, continuous levels of cAMP (see Discussion).

$E c m A$ and $S P 60$ expression begins after that of primary late genes such as $C P 2$ and $D d$ ras $D$ (Fig. 7). Both of these transcripts are completely absent from $g b f^{-}$cells, indicating an absolute requirement for GBF and/or developmental signals dependent on GBF. cAMP added for $6 \mathrm{hr}$ to cells under slow-shake conditions, which activates ecmA and SP60 in wild-type cells, cannot bypass the requirement for GBF (Fig. 8). In A15-GBF cells, the developmental expression of ecmA and SP60 is accelerated by $\sim 2 \mathrm{hr}$ (Fig. 7). The absence of these transcripts in vegetative A15-GBF cells demonstrates that, in addition to high levels of GBF, other signals are required for their expression. Unlike $C P 2$, however, this requirement cannot be met by cAMP alone, as the expression of these genes in A15-GBF cells still requires a 6-hr slow-shake incubation in the presence of cAMP (Fig. 8). Constitutive GBF expression may accelerate the fulfillment of this requirement however, as the slow + cAMP levels of SP60 and $e c m A$ transcripts are 2- and 20-fold higher, respectively, in A15-GBF than in wild-type cells.

The developmental kinetics of early-aggregation gene expression is largely unaffected in either $g b f^{-}$or Al5GBF cell lines (Fig. 7). However, in A15-GBF cells, levels of $D 2$ transcript are higher in late development and cs $A$ expression in early development is repressed. The abundant expression of $D 2$ and $\operatorname{cs} A$, as well as the weak expression of $C P 2$ transcripts, at $20 \mathrm{hr}$ in $g b f^{-}$cells may be due to these cells re-expressing early gene markers after their initial failure to proceed through development. This effect is concurrent with the observed loosening of $g b f^{-}$aggregation mounds.

\section{Discussion}

The transition between early aggregation and later morphogenesis is one of the most important, yet poorly understood, developmental changes in Dictyostelium. It is at this stage that a loosely adherent mound of cells, having chemotaxed to a central position, differentiate to form a coherent organism of distinct cell types surrounded by a sheath. The product of the GBF gene, cloned here, is clearly a critical factor in this developmental switch. Disruption of the GBF gene arrests development at the loose aggregate stage, and although it has little effect on the expression of genes involved in 
early aggregation, it virtually eliminates the activation of cell-type-specific late gene markers.

Because of the correlation between the affinity of a CA/GT-rich element for GBF in vitro and its ability to allow cAMP and developmental induction in vivo /see introductory section|, we expect that GBF acts as a transcription factor that responds to an extracellular cAMP signal at these sites. As such, it would offer the first opportunity to study signal transduction in Dictyostelium by working backwards from the level of gene activation. That GBF function is cell autonomous is consistent with this hypothesis, as is the accelerated developmental activation of late gene markers in A15-GBF cells. In addition, the lack of induction of Ddras $D$ and $C P 2$ (expressed before the high mound stage in wild-type cells) in $g b f^{-}$null cells cannot simply be the result of developmental arrest, indicating that GBF has a more direct effect on their transcription. GBF is also regulated in a manner that one might expect for a late gene activator. GBF transcript is present at low levels in starved cells and is activated as fast or faster than all tested late gene transcripts in response to cAMP. Allowing for a short delay for translation, the level of GBF activity in extracts mirrors GBF mRNA levels under all tested conditions. In accordance with these data, there is a correlation between $C P 2$ transcriptional activation (Hjorth et al. 1989) and GBF mRNA accumulation, which both reach near-maximal levels within an hour after stimulation by cAMP. Furthermore, overexpression of GBF results in the rapid activation of $C P 2$ in response to a $1-\mathrm{hr}$ incubation with cAMP ( $\sim 20$-fold higher than wild type). Although it is possible that constitutive expression of GBF causes secondary effects that allow this enhanced response to cAMP, it seems most likely that GBF is the limiting factor in this activation. Combined with the correlation between in vitro GBF binding and in vivo activation by cAMP (see introductory section) these results strongly indicate that GBF is functioning as a transcriptional activator, at the end of a signaling pathway responsive to high concentrations of cAMP.

What might be the components of a signaling pathway that results in GBF trans-activation in response to cAMP? Pharmacological studies indicate that late genes are activated by a cell-surface cAMP receptor of ligand specificity similar to the receptor responsible for chemotaxis in aggregation and distinct from the specificity of cAMP-dependent protein kinase (Schaap and van Driel 1985; Gomer et al. 1986b; Oyama and Blumburg 1986; Haribabu and Dottin 1986). Of the cloned genes encoding cAMP receptors, only $c A R 1$ (required for chemotaxis) has a null phenotype consistent with a potential requirement for GBF activation by CAMP (Sun and Devreotes 1991), as car3 nulls demonstrate wild-type development (Johnson et al. 1993) and car2 nulls form tight aggregates and express late gene markers (Saxe et al. 1993). Of the G-proteins thought to be linked to the cARs, only Ga2 has a null phenotype (similar to that of cARl null cells) consistent with a potential requirement for GBF activation (for review, see Kimmel and Firtel 1991).

Cell-surface cAMP receptors are responsible for the immediate, potential second-messenger responses to cAMP in aggregating cells, including adenylyl cyclase and guanylyl cyclase activation, and calcium influx. Of these, evidence suggests that the G-protein coupled activation of adenylyl and guanylyl cyclases are not required for late gene expression (Schaap et al. 1986; Kumagai et al. 1988; Haribabu et al. 1991). This makes sense, as these responses are adaptive and down-regulated by the continuous cAMP levels that activate late genes. The lack of a requirement for adenylyl cyclase activation renders the involvement of cAMP-dependent protein kinase PKA unlikely, especially because activation of Ddras $D$ by cAMP is unaffected in cells lacking the PKA catalytic subunit (Mann and Firtel 1991). Calcium influx in response to cAMP is developmentally regulated (peaking at $\sim 4 \mathrm{hr}$ of starvation in shaking culture), and is a nonadaptive response, making it a possible candidate for GBF activation (Bumann et al. 1984). Experiments using calcium antagonists indicate that cAMP-induced $\mathrm{Ca}^{2+}$ influx is required, to differing extents, for late gene expression (Schaap et al. 1986; Blumberg et al. 1988, 1989; Kumagai et al. 1988). Finally, mutants with similar developmental phenotypes to $g b f^{-}$cells might be defective in a gene involved in GBF activation and/or nearby upstream or downstream events. One such mutant, LagC, also results in a loose aggregate phenotype and fails to activate many late genes (I. Dynes, A. Clark, G. Shaulsky, A. Kuspa, W. Loomis and R. Firtel, in prep.).

How might GBF function to activate promoters in response to CAMP? Because GBF-binding sites are required for the expression of both prestalk and prespore promoters, and GBF is present in both cell types, it is likely that GBF is not involved in cell-type choice. This implies that other promoter elements will be required for cell-type specification and that they work in concert with GBFbinding sites. Accordingly, two prespore promoters, $S P 60$ and $P_{s p B}$, require the combination of GBF-binding sites and an additional $\mathrm{A} / \mathrm{T}$ element for their expression (Powell-Coffman and Firtel 1994; J. Powell-Coffman, G. Schnitzler, and R. Firtel, in prep.). Other studies also indicate that GBF cannot function alone as, unlike large promoter fragments, multimerized GBF binding sites are incapable of conferring late-developmental expression to disabled vegetative promoters (Pears and Williams 1988; J. Powell-Coffman et al., in prep.). Thus, GBF may only be able to act in synergy with other late-developmental transcription factors.

We propose a model for GBF function wherein GBF acts as a cell-type-nonspecific activator of late genes with GBF-binding sites in response to the continuous micromolar levels of extracellular cAMP that exist in aggregation mounds. The CAMP-activation of GBF probably works through the cAR1 receptor and may involve increases in cytosolic calcium or second messengers downstream of $\mathrm{G} \alpha 2$. We hypothesize that GBF can act immediately in the activation of the primary late genes that are induced early in the formation of the aggregate (such as CP2). The promoters of these genes may have been primed for activation by the binding of transcription factors responsive to early developmental signals 
and are awaiting active GBF protein for maximal expression. Genes activated later in development may bind GBF as soon as it is produced but require additional (perhaps cell type specific) activators in conjunction with GBF. Many of these later transcription factors, and the signaling systems required to activate them, would be produced in the first wave of GBF-activated genes. Thus, GBF and the signaling pathways required to activate it are hypothesized to constitute a developmental switch between the formation of a crude multicellular aggregate and cellular morphogenesis in Dictyostelium.

\section{Materials and methods}

\section{Extract preparation and GBF purification}

Extracts of Dictyostelium cells were made as described in Hjorth et al. (1989) with the following modifications. Tris replaced HEPES (which interferes with GBF binding) in both lysis and extraction buffers. For nuclear extracts, nuclear pellets were treated as per Hjorth et al. (1990), extracts were brought to $\sim 2.5$ $\mathrm{mg} / \mathrm{ml}$ protein and concentrated with $40 \%$ saturated ammonium sulfate, and the pellet was resuspended in and dialyzed against storage buffer [20 mM Tris (pH 8.4), $240 \mathrm{mM} \mathrm{KCl}, 20 \%$ glycerol, $0.1 \mathrm{mM}$ EDTA, $1 \mathrm{mM}$ DTT, and $0.05 \%$ Triton X-100]. The cytosolic fraction was saved and centrifuged at $100,000 \mathrm{~g}$ and dialyzed against storage buffer. Phenylmethyl sulfonyl fluoride (PMSF) $(0.1 \mathrm{mg} / \mathrm{ml})$, TPCK $(0.033 \mathrm{mg} / \mathrm{ml})$, TAME $(0.1 \mathrm{mg} /$ $\mathrm{ml})$, pepstatin $(1 \mu \mathrm{g} / \mathrm{ml})$, aprotinin $(2 \mu \mathrm{g} / \mathrm{ml})$ and chymostatin $(0.1 \mathrm{mg} / \mathrm{ml})$ were used as protease inhibitors in the lysis buffer, and at $0.3 \times$ concentration in storage buffer. For extracts of GBF mutants and wild-type controls, PMSF, pepstatin, aprotinin, and chymostatin were added to the lysis buffer, but only the first three were included in the storage buffer. Extract was diluted fourfold with equalization buffer $[6.7 \mathrm{~mm}$ Tris $(\mathrm{pH} 7.5), 0.1$ mM EDTA, $1 \mathrm{~mm}$ DTT, $0.05 \%$ Triton X-100 and $27 \mathrm{~mm} \mathrm{KCl}]$ and passed over a sephadex G-25 column equilibrated in $80 \mathrm{~mm}$ $\mathrm{KCl}$ affinity column buffer $[\mathrm{ACB} ; 5 \%$ glycerol, $3.3 \mathrm{~mm}$ Tris $(\mathrm{pH}$ 8.4), $6.7 \mathrm{~mm}$ Tris (pH 7.5), $0.1 \mathrm{~mm}$ EDTA, $1 \mathrm{~mm}$ DTT and $0.05 \%$ Triton X-100] to remove any material that might clog later columns. The flowthrough was applied to a DNA-cellulose column (Sigma) equilibrated in $80 \mathrm{~mm} \mathrm{KCl} \mathrm{ACB}$, washed with 1 column volume each of $240 \mathrm{mM} \mathrm{KCl} \mathrm{ACB}$ and $360 \mathrm{~mm} \mathrm{KCl}$ $\mathrm{ACB}$, and $\mathrm{GBF}$ was eluted with 2 column volumes of $1.1 \mathrm{M} \mathrm{KCl}$ ACB containing affinity column additives [ACAs; $10 \mathrm{~mm}$ $\mathrm{MgCl}_{2}, 1 \mathrm{mM}$ spermine, $1 \mathrm{mM}$ spermidine, $5 \mu \mathrm{g} / \mathrm{ml}$ of poly[d(I$\mathrm{Cll}$, and $0.1 \%$ Tween-20]. Fractions with activity were pooled, dialyzed into ACB lacking $\mathrm{KCl}$ to bring the $\mathrm{KCl}$ to $134 \mathrm{~mm}$ and loaded on a CAE-1 affinity column (see below) equilibrated in $134 \mathrm{~mm} \mathrm{KCl} \mathrm{ACB}$, and washed with 2 column volumes of 134 $\mathrm{mm} \mathrm{KCl} \mathrm{ACB}$. A 4-column volume linear gradient from 134-600 $\mathrm{mM} \mathrm{KCl} \mathrm{ACB}$ was run and fractions containing GBF (peaking at $\sim 290 \mathrm{mM} \mathrm{KCl}$ ) were pooled and dialyzed into DEAE buffer [DEAEB; $80 \mathrm{~mm} \mathrm{KCl}, 5 \%$ glycerol, $20 \mathrm{mM}$ Tris (pH 8.4), $0.05 \%$ Triton X-100, and $1 \mathrm{mM}$ DTT]. This was loaded onto a DEAEBequilibrated DEAE-Sepharose CL-6B (Pharmacia) column with occasional stirring of the upper column bed, and the flowthrough (containing most of the GBF activity) and $135 \mathrm{~mm}$ $\mathrm{KCl}$ DEAEB elution were collected.

\section{Affinity column}

The complementary oligonucleotides $5^{\prime}$-GATCTTTTTCACACACCCACACACTAATTTACCCCATTTTTG-3' and 5'-GATCCAAAAATGGGGTAAATTAGTGTGTGGGTGTGTGAA-
AAA $-3^{\prime}$, corresponding to the coding and transcribed strands (respectively) of CAE-1 from the SP60 promoter (Haberstroh et al. 1991), were synthesized, annealed, ligated, and then coupled to Sepharose CL2B 300 (Sigma) as detailed previously (Kadonaga 1991). With a $61 \%$ coupling efficiency, the affinity resin was 43 $\mu \mathrm{g} / \mathrm{ml}$ in CAE-1.

Mobility shift assays

Mobility shift assays were performed as described previously (Hjorth et al. 1989) with the following modifications. The subcloned CP2 G-box 43-mer oligonucleotide (p0413) was isolated by digestion with $E$ coRI and PstI to produce an 84-bp fragment, and end-labeled with $\left[\alpha^{-32} \mathrm{P}\right] \mathrm{dATP}$ and Klenow. Typically 0.05 $\mathrm{ng}$ of labeled probe was incubated in a $20-\mu 1$ reaction with 400 $\mathrm{ng}$ of poly[(dI-C)], $1 \mathrm{mg} / \mathrm{ml}$ of BSA, binding buffer, $3 \mathrm{ng}$ of competitors, and extract (added last) for 15-30 min at room temperature (with modifications noted in the figure legends). In most cases, the final binding buffer was $1 / 4 \times$ storage buffer, adjusted to account for storage buffer in extracts. At points in the purification, binding buffer was ACB $80-134 \mathrm{mM} \mathrm{KCl}$, or DEAEB or renaturation buffer (see below), and the differences in solute concentration and $\mathrm{pH}$ between these buffers do not greatly affect GBF binding (data not shown). The cloned CP2 43-mer and 43-mer mutant competitors (Hjorth et al. 1989) were isolated with EcoRI and PstI. The SP60 CAE-1 oligonucleotide also binds GBF and functions as a strong competitor (J. Powell-Coffman, G. Schnitzler, and R. Firtel, in prep.|, and was used as described in Haberstroh et al. (1991).

One unit of GBF activity is defined as the amount required to produce a $50 \%$ shift in the presence of $50 \mathrm{ng}$ of poly[d(I-C)], as determined by laser densitometry. The number of apparent units in any mobility shift reaction is determined by comparison to a curve of titration with extract. Because the percent bound decreases roughly linearly with increasing $\log$ poly[d(IC)l, a correction can be made from apparent units at any given concentration of poly[d(I-C)] to units at $50 \mathrm{ng}$ of poly[(dI-C)].

\section{Renaturation of activity from SDS-PAGE}

Elution and renaturation were performed as described previously (Hager and Burgess 1980) with modifications. Briefly, SDS-PAGE lanes containing GBF fractions were stained with Coomassie blue, size ranges or specific bands were excised, crushed with a glass Dounce homogenizer into elution buffer [EB; 0.1\% SDS, $50 \mathrm{~mm}$ Tris (pH 7.9), 0.1 mM EDTA, 5 mM DTT, $0.1 \mathrm{mg} / \mathrm{ml}$ of BSA, and $150 \mathrm{~mm} \mathrm{KCl}$, and incubated overnight on a rolling platform. Gel fragments were spun down, and the supernatant was precipitated with 4 volumes of cold acetone, washed with $80 \%$ acetone $/ 20 \%$ EB lacking SDS, resuspended in $6 \mathrm{M}$ guanidinium hydrochloride renaturation buffer $\left[\mathrm{RB}_{;}, 10 \mathrm{mM}\right.$ Tris (pH 8.0), $50 \mathrm{~mm} \mathrm{KCl}, 1 \mathrm{~mm}$ DTT, $0.1 \mathrm{~mm}$ EDTA, $5 \%$ glycerol, $0.05 \%$ Triton X-100, and $0.1 \mathrm{mg} / \mathrm{ml}$ of BSA], incubated at room temperature for $1 \mathrm{hr}$, diluted 50 -fold with ice-cold $\mathrm{RB}$ and incubated on ice $2 \mathrm{hr}$ before use in a mobility-shift assay. Recovery of binding activity was $\sim 1 \%$.

\section{Isolation of peptides and microsequencing}

DEAE flowthrough and $135 \mathrm{~mm} \mathrm{KCl}$ fractions /containing 144,000 units of GBF activity, or $\sim 36 \mu$ g protein/ were precipitated with $13 \%$ TCA, washed with acetone, resuspended in $1 \times$ SDS-PAGE loading buffer, run on a $7.5 \%$ SDS-PAGE gel, and electroblotted to PVDF membranes (Immobilon-P, Millipore). The filter was stained with amido black, and excised bands were digested with trypsin. Released peptides were isolated by HPLC, and selected fractions were sequenced as described previously 
(Fischer et al. 1991). To control for possible contamination of the abundant $37-\mathrm{kD}$ protein (Fig. 1B), only those HPLC peaks present in the $92-\mathrm{kD}$ band profile and not in the $37-\mathrm{kD}$ band profile were selected for microsequencing.

\section{PCR and CDNA cloning}

Sense and antisense pairs of degenerate oligonucleotides were made to correspond to the regions of highest confidence for three of the peptide sequences. PCR reactions with paired sense and antisense oligonucleotides were performed as described previously (Mann and Firtel 1991) with CsCl-purified Dictyostelium genomic DNA. A combination of the 1037 sense oligonucleotide [5'-GTCTGGATCCGC(A/T/C)TT/T/C)AC(A/T/ $\mathrm{C} \mid \mathrm{CC}(\mathrm{A} / \mathrm{T}) \mathrm{GG}(\mathrm{A} / \mathrm{T} / \mathrm{C}) \mathrm{AT}(\mathrm{A} / \mathrm{T} / \mathrm{C}) \mathrm{ACNAA}]$ and 1035 antisense oligonucleotide [5'-GTCTCTGCAGCNCCN/C/A)(A/ C|NGGNGT(A/G)AANGG] resulted in an $\sim 480$ bp product at 48 and $53^{\circ} \mathrm{C}$ annealing temperatures. These reactions were extracted with phenol/ $\mathrm{CHCl}_{3}$, ethanol precipitated, and digested with $\mathrm{BamHI}$ and PstI, followed by phenol/ $\mathrm{CHCl}_{3}$ extraction, ethanol precipitation, and direct ligation into pSP72 (Promega). The specificity of the subcloned PCR poduct GBF-12 was confirmed by sequencing with Sequenase (U.S. Biochemical Corp.). A $\lambda$ ZAP (Stratagene) cDNA library was prepared from RNA isolated from Dictyostelium cells developed for $12-16 \mathrm{hr}$ as per the manufacturer's instructions and was screened using the PCR product and/or cDNA fragments from earlier screens as probes, to yield multiple overlapping cDNA clones.

\section{General molecular biology and culturing of Dictyostelium strains}

These experiments used the wild-type axenic strain KAx-3 and its thymidine auxotrophic derivative JH10 (Mann and Firtel 1991; Hadwiger and Firtel 1992). Procedures were performed as described in the following references, with any modifications noted: Dictyostelium culturing, development, and DNA and RNA isolation (Nellen et al. 1987), with $100 \mu \mathrm{M}$ thymidine added to the HL5 medium of untransformed JH10 cells; fastand slow-shake experiments (Mehdy et al. 1983; Mehdy and Firtel 1985); electroporation (Dynes and Firtel 1989), with neo ${ }^{\mathrm{R}}$ transformants maintained in $15 \mu \mathrm{g} / \mathrm{ml} \mathrm{G418;} \beta$-galactosidase staining (Haberstroh and Firtel 1990) with modifications described in Powell-Coffman and Firtel (1994); Percoll gradients (Kubahara et al. 1993). Southern and Northern blots were probed with random-primed probes (Powell et al. 1992). The L9 genedisruption construct was digested with EcoRV and ApaI before electroporation. A T3-TnT-coupled in vitro transcription/ translation kit (Promega) was used as per the manufacturer's instructions, except that plasmid was linearized with ApaI before use.

\section{Plasmid constructs}

The gene-disruption construct (L9) was made by insertion of an $\sim 3$-kb fragment containing the Thy1 gene (Dynes and Firtel 1989 ) into GBF cDNA sequences (encompassing the sequences between 24 and 2424 bp $3^{\prime}$ of the initiation codon) between the HincII and EcoRI sites 1678 and 1403 bp $3^{\prime}$ of the ATG, respectively), in the pBluescript $\mathrm{SK}^{-}$(pBSK ${ }^{-}$; Stratagene) vector (Fig. 2). The Dictyostelium A15-GBF expression construct (N27) was made by placement of cDNA sequences encompassing the complete GBF ORF (between 45 bp $5^{\prime}$ and 2424 bp $3^{\prime}$ of the initiation codon/ behind the Act15 promoter in the EXP4 ${ }^{+}$Dictyostelium expression vector (J. Dynes, A. Clark, G. Shaulsky,
A. Kuspa, W. Loomis, and R.A. Firtel, in prep.). To construct the transcription/translation plasmid (R20) the PstI-KpnI fragment from N27 (containing 5' GBF seqeunces) was subcloned into $\mathrm{pBSK}^{-}$. Approximately $15 \mathrm{ng}$ of miniprep DNA from this subclone was amplified by PCR at an annealing temperature of $37^{\circ} \mathrm{C}$, with the $\mathrm{T} 7$ promoter primer and an oligonucleotide (5'-GTTTGAGCTCTAGACACCATGCTGTCAACTCATCATCACCAAGG) designed to optimize the region surrounding the GBF ATG for translation in reticulocyte lysates. The $\sim 750$-bp product was digested with $\mathrm{XbaI}$ and $\mathrm{KpnI}$, purified (see above for details|, and cloned, along with the 1.7-kb KpnI-XhoI N27 fragment (containing 3' GBF seqeunces), into the $X b a \mathrm{I}-$ XhoI sites of $\mathrm{pBSK}^{-}$. The Act15-lacZ construct is described in Mann and Firtel (1993).

\section{Acknowledgments}

We are indebted to Minkyu Park for excellent technical assistance. We would like to thank J.A. Powell-Coffman and L. Haberstroh for helpful suggestions over the course of this work. This work was supported by USPHS grants to RAF.

The publication costs of this article were defrayed in part by payment of page charges. This article must therefore be hereby marked "advertisement" in accordance with 18 USC section 1734 solely to indicate this fact.

\section{References}

Altschul, S.F., W. Gish, W. Miller, E.W. Myers, and D.J. Lipman. 1990. Basic local alignment search tool. J. Mol. Biol. 215: 403-410.

Berks, M. and R.R. Kay. 1990. Combinatorial control of cell differentiation by cAMP and DIF-1 during development of Dictyostelium discoideum. Development 110: 977-984.

Blumberg, D.D., J.F. Comer, and K.G. Higginbotham. 1988. A $\mathrm{Ca}^{2+}$-dependent signal transduction system participates in coupling expression of some cAMP-dependent prespore genes to the cell surface receptor. Dev. Genet. 9: 359-369.

Blumberg, D.D., J.F. Comer, and E.M. Walton. 1989. $\mathrm{Ca}^{2+}$ antagonists distinguish different requirements for cAMP-mediated gene expression in the cellular slime mold, Dictyostelium discoideum. Differentiation 41: 14-21.

Bruder, J.T., G. Heidecker, and U.R. Rapp. 1992. Serum-, TPA-, and Ras-induced expression from Ap-1/Ets-driven promoters requires Raf-1 kinase. Genes \& Dev. 6: 545-556.

Bumann, J., B. Wurster, and D. Malchow. 1984. Attractant induced changes and oscillations of the extracellular $\mathrm{Ca}^{2+}$ concentration in suspensions of differentiating Dictyostelium cells. J. Cell Biol. 98: 173-178.

Burki, E., C. Anjard, J.C. Scholder, and C.D. Reymond. 1991. Isolation of two genes encoding putative protein kinases regulated during Dictyostelium discoideum development. Gene 102: 57-65.

Ceccarelli, A., H. Mahbubani, and J.G. Williams. 1991. Positively and negatively acting signals regulating stalk cell and anterior-like cell differentiation in Dictyostelium. Cell 65: 983-989.

Ceccarelli, A., H.J. Mahbubani, R. Insall, G. Schnitzler, R.A. Firtel, and J.G. Williams. 1992. A G-rich sequence element common to Dictyostelium genes which differ radically in their patterns of expression. Dev. Biol. 152: 188-193.

Chou, P.Y. and G.D. Fasman. 1978. Prediction of the secondary structure of proteins from their amino acid sequence. $A d v$. Enzymol. Relat. Areas Mol. Biol. 47: 45-148.

Courey, A.J. and R. Tjian. 1988. Analysis of Sp1 in vivo reveals 
multiple transcriptional domains including a novel glutamine-rich activation motif. Cell 55: 887-898.

Datta, S. and R. Firtel. 1987. Identification of the sequences controlling cyclic AMP regulation and cell-type-specific expression of a prestalk-specific gene in Dictyostelium discoideum. Mol. Cell. Biol. 7: 149-159.

- 1988. An 80-bp cis-acting regulatory region controls cAMP and development regulation of a prestalk gene in Dictyostelium. Genes \& Dev. 2: 294-304.

Dynes, J.L. and R.A. Firtel. 1989. Molecular complementation of a genetic marker in Dictyostelium using a genomic DNA library. Proc. Natl. Acad. Sci. 86: 7966-7970.

Early, A.M., D.T. Gaskell, and J.G. Williams. 1993. Two distinct populations of prestalk cells within the tip of the migratory Dictyostelium slug with differing fates at culmination. Development 118: 353-362.

Esch, R.K. and R.A. Firtel. 1991. cAMP and cell sorting control the spatial expression of a developmentally essential celltype-specific ras gene in Dictyostelium. Genes \& Dev. 5: 921.

Esch, R.K., P.K. Howard, and R.A. Firtel. 1992. Regulation of the Dictyostelium cAMP-induced, prestalk-specific DdrasD gene: Identification of cis-acting elements. Nucleic Acids Res. 20: 1325-1332.

Fischer, W.H., D. Karr, B. Jackson, M. Park, and W. Vale. 1991. Microsequence analysis of proteins purified by gel electrophoresis. Methods Neurosci. 6: 69-84.

Fosnaugh, K.L. and W.F. Loomis. 1991. Coordinate regulation of the spore coat genes in Dictyostelium discoideum. Dev. Genet. 12: 123-132.

- 1993. Enhancer regions responsible for temporal and cell-type-specific expression of a spore coat gene in Dictyostelium. Dev. Biol. 157: 38-48.

Garnier, J., D.J. Osguthorpe, and B. Robson. 1978. Analysis of the accuracy and implications of simple methods for predicting the secondary structure of globular proteins. J. Mol. Biol. 120: $97-120$.

Gerisch, G., H. Fromm, A. Huesgen, and U. Wick. 1975. Control of cell-contact sites by cyclic AMP pulses in differentiating Dictyostelium cells. Nature 255: 547-549.

Gomer, R., S. Datta, and R. Firtel. 1986a. Cellular and subcellular distribution of a cAMP regulated prestalk protein and prespore protein in Dictyostelium discoideum: a study on the ontogeny of prestalk and prespore cells. I. Cell Biol. 103: 1999-2015.

Gomer, R., D. Armstrong, B. Leichtling, and R. Firtel. 1986b. cAMP induction of prespore and prestalk gene expression in Dictyostelium is mediated by the cell surface cAMP receptor. Proc. Natl. Acad. Sci. 83: 8624-8628.

Grantham, R., C. Gautier, M. Gouy, M. Jacobzone, and R. Mercier. 1981. Codon catalog usage is a genome strategy modulated for gene expressivity. Nucleic Acids Res. 9: 43-74.

Haberstroh, L. and R.A. Firtel. 1990. A spatial gradient of expression of a cAMP-regulated prespore cell-type-specific gene in Dictyostelium. Genes \& Dev. 4: 596-612.

Haberstroh, L., J. Galindo, and R.A. Firtel. 1991. Developmental and spatial regulation of a Dictyostelium prespore gene: cisacting elements and a cAMP-induced, developmentally regulated DNA binding activity. Development 113: 947-958.

Hadwiger, J.A. and R.A. Firtel. 1992. Analysis of Ga4, a G-protein subunit required for multicellular development in Dictyostelium. Genes \& Dev. 6: 38-49.

Hager, D.A. and R.R. Burgess. 1980. Elution of proteins from sodium dodecyl sulfate-polyacrylamide gels, removal of sodium dodecyl sulfate, and renaturation of enzymatic activity: Results with sigma subunit of Escherichia coli RNA polymerase, wheat germ DNA topoisomerase, and other enzymes. Anal. Bioch. 109: 76-86.

Haribabu, B. and R. Dottin. 1986. Pharmacological characterization of cyclic AMP receptors mediating gene-regulation in Dictyostelium discoideum. Mol. Cell. Biol. 6: 2402-2408.

Haribabu, B., J. Pavlovic, S.R. Bodduluri, J.F. Doody, B.D. Ortiz S. Mullings, B. Moon, and R.P. Dottin. 1991. Signal transduction pathways involved in the expression of the uridine diphosphoglucose pyrophosphorylase gene of Dictyostelium discoideum. Dev. Genet. 12: 35-44.

Hjorth, A.L., N.C. Khanna, and R.A. Firtel. 1989. A trans-acting factor required for cAMP-induced gene expression in Dictyostelium is regulated developmentally and induced by cAMP. Genes \& Dev. 3: 747-759.

Hjorth, A.L., C. Pears, J.G. Williams, and R.A. Firtel. 1990. A developmentally regulated trans-acting factor recognizes dissimilar G/C-rich elements controlling a class of cAMPinducible Dictyostelium genes. Genes \& Dev. 4: 419-432.

Jermyn, K.A. and J.G. Williams. 1991. An analysis of culmination in Dictyostelium using prestalk and stalk-specific cell autonomous markers. Development 111: 779-787.

Jermyn, K.A., M. Berks, R.R. Kay, and J.G. Williams. 1987. Two distinct classes of prestalk-enriched mRNA sequences in Dictyostelium discoideum. Development 100: 745-755.

Johnson, R.L., C.L. Saxe III, R. Gollop, A.R. Kimmel, and P.N. Devreotes. 1993. Identification and targeted gene disruption of $c A R 3$, a cAMP receptor subtype expressed during multicellular stages of Dictyostelium development. Genes \& Dev. 7: 273-282.

Kadonaga, J.T. 1991. Purification of sequence-specific binding proteins by DNA affinity chromatography. Methods Enzymol. 208: 10-23.

Kimmel, A.R. and R.A. Firtel. 1991. cAMP signal transduction pathways regulating development of Dictyostelium discoideum. Curr. Opin. Genet. Dev. 1: 383-390.

Knecht, D., S. Cohen, W. Loomis, and H. Lodish. 1986. Developmental regulation of Dictyostelium discoideum actin gene fusions carried on low-copy and high-copy transformation vectors. Mol. Cell. Biol. 6: 3973-3983.

Kozak, M. 1983. Comparison of initiation of protein synthesis in procaryotes, eukaryotes, and organelles. Microbiol. Rev. 47: $1-45$.

Kubahara, Y., M. Maeda, and K. Okamoto. 1993. Analysis of the maturation process of prestalk cells in Dictyostelium discoideum. Exp. Cell Res. 207: 107-114.

Kumagai, A., S.K. Mann, M. Pupillo, G. Pitt, P.N. Devreotes, and R.A. Firtel. 1988. A molecular analysis of $G$ proteins and control of early gene expression by the cell-surface cAMP receptor in Dictyostelium. Cold Spring Harbor Symp. Quant. Biol. 8: 675-685.

Kuspa, A., D. Maghakian, P. Bergesch, and W.F. Loomis. 1992. Physical mapping of genes to specific chromosomes in Dictyostelium discoideum. Genomics 13: 49-61.

Kyte, J. and R.F. Doolittle. 1982. A simple method for displaying the hydropathic character of a protein. J. Mol. Biol. 157: 105132.

Lennox, W.R. and L.H. Cohen. 1989. Analysis of histone subtypes and their modified forms by polyacrylamide gel electrophoresis. Methods Enzymol. 170: 532-549.

Ma, P.C. and C.H. Siu. 1990. A pharmacologically distinct cyclic AMP receptor is responsible for the regulation of $g p 80$ expression in Dictyostelium discoideum. Mol. Cell. Biol. 10: $3297-3306$

Mann, S.K.O. and R.A. Firtel. 1987. Cyclic AMP regulation of early gene expression in Dictyostelium discoideum: Mediation via the cell surface cyclic AMP receptor. Mol. Cell. Biol. 
7: 458-469.

. 1991. A developmentally regulated, putative serine/ threonine protein kinase is essential for development in Dictyostelium. Mech. Dev. 35: 89-101.

1993. cAMP-dependent protein kinase differentially regulates prestalk and prespore differentiation during Dictyostelium development. Development 119: 135-146.

Mehdy, M. and R. Firtel. 1985. A secreted factor and cyclic AMP jointly regulate cell-type-specific gene expression in Dictyostelium discoideum. Mol. Cell. Biol. 5: 705-713.

Mehdy, M.C., D. Ratner, and R.A. Firtel. 1983. Induction and modulation of cell type specific gene expression in Dictyostelium. Cell 32: 763-771.

Muller-Immergluck, M.M., W. Schaffner, and P. Matthias. 1990. Transcription factor Oct-2A contains functionally redundant activating domains and works selectively from a promoter but not from a remote enhancer position in non-lymphoid (HeLa) cells. EMBO I. 9: 1625-1634.

Nellen, W., S. Datta, C. Reymond, A. Sivertsen, S. Mann, T. Crowley, and R.A. Firtel. 1987. Molecular biology in Dictyostelium: Tools and applications. Methods Cell Biol. 28: 67100.

Oyama, M. and D. Blumberg. 1986. Interaction of cAMP with the cell surface receptor induces cell type specific messenger RNA accumulation in Dictyostelium discoideum. Proc. Natl. Acad. Sci. 83: 4819-4823.

Pabo, C.O. and R.T. Sauer. 1992. Transcription factors: Structural families and principles of DNA recognition. Annu. Rev. Biochem. 61: 1053-1095.

Pavlovic, J., B. Haribabu, and R.P. Dottin. 1989. Identification of a signal transduction response sequence element necessary for induction of a Dictyostelium discoideum gene by extracellular cyclic AMP. Mol. Cell. Biol. 9: 4660-4669.

Pears, C. and J. Williams. 1987. Identification of a DNA-sequence element required for efficient expression of a developmentally regulated and cAMP-inducible gene of Dictyostelium discoideum. EMBO I. 6: 195-200.

1988. Multiple copies of a G-rich element upstream of a cAMP-inducible Dictyostelium gene are necessary but not sufficient for efficient gene expression. Nucleic Acids Res. 16: 8467-8486.

Pears, C., H. Mahbubani, and J. Williams. 1985. Characterization of two highly diverged but developmentally co-regulated cysteine proteinase genes in Dictyostelium discoideum. Nucleic Acids Res. 13: 8853-8866.

Pitt, G.S., N. Milona, J. Borleis, K.C. Lin, R.R. Reed, and P.N. Devreotes. 1992. Structurally distinct and stage-specific adenylyl cyclase genes play different roles in Dictyostelium development. Cell 69: 305-315.

Powell, J.A., J. Galindo, and R.A. Firtel. 1992. A negative transcriptional control region of a developmentally-regulated gene co-localizes with the origin of replication of an endogenous plasmid in Dictyostelium. Nucleic Acids Res. 20: $2795-2802$.

Powell-Coffman, J.A. and R.A. Firtel. 1994. Characterization of a novel Dictyostelium discoideum prespore-specific gene, $P s p B$, reveals conserved regulatory sequences. Development (in press).

Reymond, C., R. Gomer, M. Mehdy, and R. Firtel. 1984. Developmental regulation of a Dictyostelium gene encoding a protein homologous to mammalian ras protein. Cell 39: 141148.

Rutherford, C.L., R.B. Peery, J.F. Sucic, Y.Z. Yin, P.V. Rogers, S. Luo, and O. Selmin. 1992. Cloning, structural analysis, and expression of the glycogen phosphorylase- 2 gene in Dictyostelium. J. Biol. Chem. 267: 2294-2302.
Saxe III, C.L., G.T. Ginsburg, J.H. Louis, R. Johnson, P.N. Devreotes, and A.R. Kimmel. 1993. CAR2, a prestalk cAMP receptor required for normal tip formation and late development of Dictyostelium discoideum. Genes \& Dev. 7: 262272.

Schaap, P. and R. van Driel. 1985. Induction of post-aggregative differentiation in Dictyostelium discoideum by cAMP-evidence of involvement of the cell surface cAMP receptor. Exp. Cell Res. 159: 388-398.

Schaap, P., M.M. van Lookeren-Campagne, R. van Driel, W. Spek, P.J. van Haastert, and J. Pinas. 1986. Postaggregative differentiation induction by cyclic AMP in Dictyostelium: Intracellular transduction pathway and requirement for additional stimuli. Dev. Biol. 118: 52-63.

Seipel, K., O. Georgiev, and W. Schaffner. 1992. Different activation domains stimulate transcription from remote ("enhancer") and proximal ("promoter") positions. EMBO $J$. 11: 4961-4968.

Shaw, D.R., H. Richter, R. Giorda, T. Ohmachi, and H.L. Ennis. 1989. Nucleotide sequences of Dictyostelium discoideum developmentally regulated cDNAs rich in (AAC) imply proteins that contain clusters of asparagine, glutamine, or threonine. Mol. Gen. Genet. 218: 453-459.

Sun, T.J. and P.N. Devreotes. 1991. Gene targeting of the aggregation stage cAMP receptor cAR1 in Dictyostelium. Genes \& Dev. 5: 572-582.

Wharton, K.A., B. Yedvonbnick, V.G. Finnerty, and S. Artavanis-Tsakonas. 1985. opa: A novel family of transcribed repeats shared by Notch locus and other developmentally regulated loci in D. melanogaster. Cell 40: 55-62.

Williams, J.G. 1991. Regulation of cellular differentiation during Dictyostelium morphogenesis. Curr. Opin. Genet. Dev. 1: 358-362.

Williams, J.G., A. Ceccarelli, S. McRobbie, H. Mahbubani, R.R. Kay, A. Early, M. Berks, and K. Jermyn. 1987. Direct induction of Dictyostelium prestalk gene expression by DIF provides evidence that DIF is a morphogen. Cell 49: 185-192. 


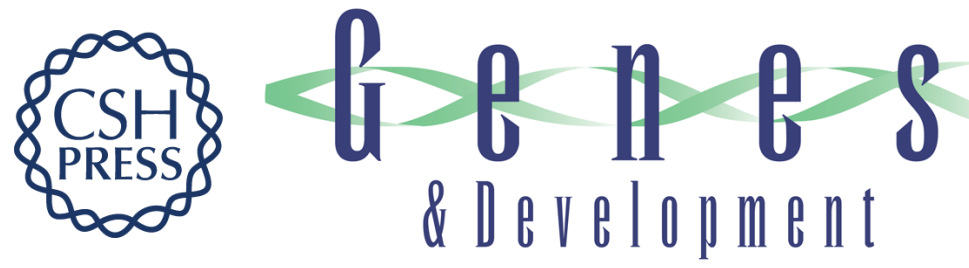

\section{Cloning and characterization of the G-box binding factor, an essential component of the developmental switch between early and late development in Dictyostelium.}

G R Schnitzler, W H Fischer and R A Firtel

Genes Dev. 1994, 8:

Access the most recent version at doi:10.1101/gad.8.4.502

References This article cites 72 articles, 29 of which can be accessed free at: http://genesdev.cshlp.org/content/8/4/502.full.html\#ref-list-1

License

Email Alerting Service

Receive free email alerts when new articles cite this article - sign up in the box at the top right corner of the article or click here.

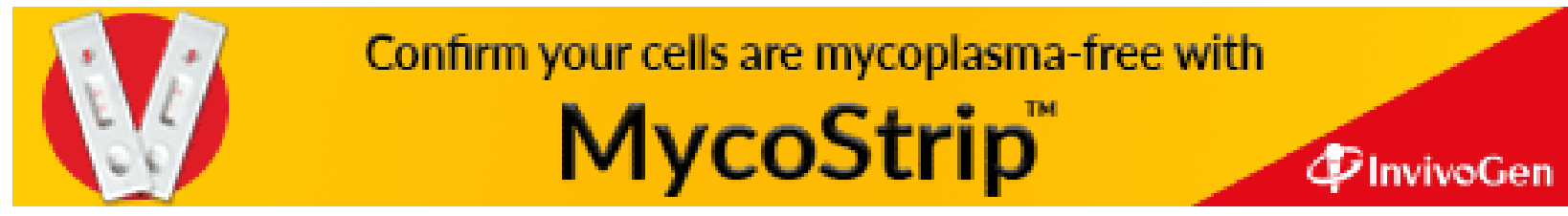

